\title{
HUKUMAN MATI TERHADAP NARAPIDANA TERORISME DALAM PERLINDUNGAN HAK ASASI MANUSIA
}

\author{
I Putu Gde Iwan Putra Darmayatna, I Made Sepud \& Ni Made Sukaryati Karma \\ Fakultas Ilmu Hukum, Universitas Warmadewa, Denpasar-Bali, Indonesia \\ iwanputra080@gmail.com, sepudrnade@gmail.com \& sukariati64@gmail.com
}

\begin{abstract}
Abstrak
Hukuman mati di Indonesia selalu menjadi perdebatan karena belum berlandaskan UUD 1945. Hukuman mati berada di kasta hukum tertinggi sebagai hukuman terberat di Dunia, yang diberikan kepada seorang terpidana. Penelitian ini bertujuan untuk menelaah pengaturan hukuman mati terhadap terorisme dalam kaitannya dengan perlindungan hak asasi manusia dan mengkaji upaya hukum narapidana terorisme untuk mendapatkan keringan hukum. Penelitian ini menggunakan tipe penelitian hukum normatif, teknik dalam pengumpulan bahan pada penelitian ini dilakukan dengan studi kepustakaan. Penelitian ini menggunakan pendekatan perundang-undangan dalam menganalisis data. Hasil dari penelitian ini menunjukan adanya konflik antara pengaturan hukuman mati dengan HAM. Pengaturan hukuman mati terhadap terorisme dalam kaitannya dengan perlindungan HAM menyebabkan munculnya berbagai pendapat dan perdebatan yang dimana hukuman mati dianggap melanggar HAM dan ada yang menganggap hukuman ini harus tetapdiberlakukan. Upaya yang dilakukan terorisme untuk mendapatkan keringanan hukum merupakan kebijakan hukum yang memiliki ide dasar dalam perlindungan HAM. Upaya hukum mengajukan banding, kasasi, peninjauan kembali hingga pengajuan grasi meminta pengampunan Presiden terhadap narapidana untuk mengurangi hukum.
\end{abstract}

Kata Kunci: Hak asasi manusia, Hukuman mati, Tindak pidana terorisme.

\begin{abstract}
Indonesia the death penalty has always been a matter of arguments because isn't based 011 the 1945 Constitution, the death penalty is in highest legal caste as the toughest punishment in the world. The research aims to examine the regulation of the death penalty against terrorism in relation to the protection of human rights and to analyze the legal measures against terrorism convicts to obtain legal relief. This research used the type of normative research, the techniques in the data collection are based on literature study. This research used statutory approach, to analyze the data. The results of this research indicate a conflict between the regulation of the death penalty and human rights. The regulation of the death penalty against terrorism in the relation to the protection of human rights has resulted in the emergence of various opinions and debates where the death penalty is considered to violate human rights and some consider this punishment to be applied. The effort by terrorism to obtain Juggleries a legal policy that has a basic idea in protecting human rights. Legal efforts to file an appeal, cassation, review to filing clemency request forgiveness from the President of the prisoners to reduce the law.
\end{abstract}

Keywords: Death penalty, Criminal acts of terrorism, Human Rights

\section{PENDAHULUAN}

Pentingnya peranan Perundang-undangan dalam rangka pembangunan masyarakat dalam suatu Negara yang sedang berkembang yang mencita-citakan pembangunan di semua bidang, baik dibidang ekonomi dan sosial budaya, yang tetap menduduki tempat yang dominan dalam usaha pembi naan hukum yang diatur dalam Undang-undang Dasar Negara Republik Indonesia Tahun 1945. Hukum yang berlaku bagi Negara Indonesia berpijak pada UUD Negara Republik Indonesia Tahun 1945 UUD tersebut merupakan hukum dasar tertulis yang menjadi kekuatan atau norma dari segala bentuk peraturan perundang-undangan yang berlaku sekarang di Negara 
Kesatuan Republik Indonesia. Paragraf keempat Pembukaan Undang-Undang Dasar Negara Republik Indonesia Tahun 1945 menentukan berbagai maksud dan tujuan dibentuknya Republik Indonesia.

Pemerintah Republik Indonesia dibebani dan bertanggung jawab atas amanat sebagaimana dikemukakan pada pembukaan UUD Negara Republik Indonesia Tahun 1945, untuk melindungi rakyat Indonesia dan segala pertumpahan darah di Indonesia dalam hal tersebut Negara berkewajiban melindungi segenap warga Negara terhadap dari berbagai macam ancaman kejahatan Nasional, Transnasional, maupun kejahatan lntemasional. Menurut amanat ini, penerapan hukuman mati menjadi alasan penerapan undang-undang tersebut dianggap kontroversial dan menarik perhatian karena belum berdasarkan pada UUD tahun 1945 Negara Republik Indonesia adalah.

Mengenai jenis-jenis hukuman yang diatur dalam bab II KUHP mengenai pidana pokok, dalam berbagai bentuk peraturan perundang-undangan saat ini, tidak mempunyai ketentuan ataupun definisni yang mengatur dari pembahasan mengenai pidana mati ini. Pengertian tersebut termuat dalam Pasal 1 angka 3 dari Peraturan Komisioner Kepolisian Negara Republik Indonesia (Tata cara melakukan Pelaksanaan Pidana Mati No.12 Tahun 2010). Pengertian tersebut dianggap belum cukup dalam menggambarkan makna dari hukuman mati. Pengertian ini hanya dapat dipahami bahwa dari hukuman tersebut merupakan salah satu jenis hukuman yang dijatuhkan oleh hakim. Praktik hukuman mati di Negara Indonesia, baik eksekutif maupun legislatif telah bersepakat terhadap kedudukan terorisme. erorisme merupakan kejahatan lintas negara dan bahkan merupakan tindak kejahatan yang sangat terorganisasi dan memiliki jaringan yang sangat luas, dimana kejahatan ini dapat mengancam kedamaian dan kenyamanan secara nasional maupun international (Firmansyah, 2011). Terorisme Hingga hari ini sejumlah narapidana kasus terorisme seperti Aman Abdurrahman telah divonis dan ditetapkan sebagai terpidana mati berdasarkan putusan pengadilan dan dalam masa tunggu pelaksanaan dieksekusi. Undang undang nomor 5 Tahun 2018 tentang perubahan dari Undang-undang Nomor 15 Tahun 2003, dibentuk dengan berbagai pertimbangan. Dari beberapa pertimbangan tersebut muncullah Hukuman mati terhadap teorisme yang berada di dalam pasal 6 UU No. 5 Tahun 2018.

Hukuman mati menimbulkan konflik dan akan menimbulkan adanya Pro dan kontra disetiap ahli maupun pakar hukum, para tokoh penggerak hak asasi manusia, tokoh masyarakat maupun masyarakat yang akan tetap mengandalkan pemikiran yang seruju maupun yang kurang seruju kepada lembaga-lembaga yang berwenang terhadap hukuman mati karena alasan yang logis dan rasional. (Prakoso,1987) Konflik terhadap hukuman mati tersebut, Kelompok yang kontra sangat menentang jika hukuman tersebut tetap diberlakukan serta masih digunakan karena dianggap melanggar Hak Asasi Manusia. Negara maupun masyarakat lndonesia senantiasa mengakui dan akan selalu menjaga semua bentuk hak asasi manusia, dan kebebasan mendasar dari diri manusia, karena merupakan hak yang harus melekat dan tidak mungkin terpisahkan dari umat manusia yang dimana harus selalu dilindungi, dihormati, dan dipelihara guna meningkatkan harkat dan martabat terhadap kemanusiaan, kesejahteraan, kebahagiaan, dan kearifan maupun keadilan disetiap manusia. Bahkan hak untuk hidup disertakan penegasannya sangat diakui sebagai hak yang tidak dapat untuk dikurangi didalam suatu kondisi maupun atau situasi bagaimanapun yang telah diatur dalam pasal 28 huruf 1 angka (1) UUD Negara Republik Indonesia. Hal tersebut telah mengatur dan menjamin di dalam UU No. 39 tahun 1999 yaitu mengenai hak manusia untuk hidup. Hak untuk hidup adalah hak yang bersifat mutlak dan dimiliki oleh setiap orang dan termasuk dalam kategori hak yang tidak dapat direduksi (Smith, 2008). Terkait Pasal 6 UU No. 5 Tahun 2018 perubahan dari UU No. 15 Tahun 2003 Terorisme dengan pasal 4 UU No. 39 Tahun 1999 mengenai HAM, menimbulkan suatu konflik norma antara hukum yang mengatur hukuman mati terhadap terorisme dengan perlindungan HAM yang terjadi sekarang.

Beberapa penelitian terdahulu yang relevan dengan penelitian ini yang membahas mengenai hukuman mati di Indonesia. Menurut (arief, 2019) problematika hukuman mati hingga saat ini masih menjadi perbincangan yang cukup diperdebatkan. Dalam Kitab Undang-undang Hukum Pidana dan beberapa peraturan perundang-undangan di Indonesia, ancaman pidana mati 
masih tetap dipertahankan, sedangkan para aktifis HAM mengeritik mengenai peraturan ini. Oleh karenanya dirancanglah Undang-Undang Pidana baru yang dimana memberikan kompromi bagi terpidana hukuman mati, terkecuali bagi pelaku kejahatan luar biasa. Pada penelitian selanjutnya menjelaskan penjatuhan pidana mati di Indonesia dalam kacamata Hak Asasi Manusia (Anjari, 2018). (Sumanto, 2004) Menelaah mengenai kontradiksi hukuman mati di indonesia dipandang dari aspek hak asasi manusia. agama dan para ahli hukum. Penelitian ini bertujuan untuk menelaah pengaturan hukuman mati terhadap terorisme dalam kaitannya dengan perlindungan hak asasi manusia dan mengkaji upaya hukum narapidana terorisme untuk mendapatkan keringan hukum.

\section{METODE PENELITIAN}

Penelitian yang akan digunakan untuk penelitian ini adalah penelitian hukum normatif. Penelitian hukum normatif adalah penelitian hukum yang mengkaji hukum perundang-undangan melalui segala aspek. Dalam penelitian ini terdapat adanya konflik terhadap norma hukum yang dimuat dalam pasal 6 UU No. 5 Tahun 2018 dengan pasal 4 UU No. 39 tahun 1999 Tentang HAM. Pendekatan masalah yang dipakai yaitu pendekatan Perundang-undangan dan pendekatan konsep. Pendekatan Perundang-undangan dengan mengkaji makna atau istilah yang digunakan dalam suaru perundang-undangan yang berlaku mengenai hukuman mati terhadap narapidana terorisme dalam perlindungan hak asasi manusia. Pendekatan konseptual yaitu pendekatan dengan menggunakan konsep-konsep yang dikemukakan para ahli yang ada hubunganya dengan hukuman mati terhadap narapidana terorisme. Sumber berbagai bahan hukum yang dipakai dalam penelitian ini adalah sumber bahan hukum primer dan sekunder. Sumber untuk bahan-bahan hukum primer merupakan bahan otoritas dan dijadikan sumber suatu Penelitian, dimana bahan yang mengkaji Perundang-undangan yang berlaku. Bahan hukum diperoleh dari berbagai perpustakaan seperti buku-buku referensi, jurnal hukum, dan yang lain terkait dengan permasalahan. Teknik pengumpulan dan penggunaan bahan hukum seperti penelitian perpustakaan yang dilakukan dengan mengumpulkan berbagai literatur hukum yang berupa studi dokumen melalui teknik pencatatan bahan bacaan dari berbagai teori ilmiah, peraturan dan mediamedia elektronik. Analisis bahan hukum yang dapat dikumpulkan, kemudian diolah dan dianalisis menggunakan argumentasi hukum agar adanya konsep suatu argumentasi yang ditujukan untuk memperjelas suatu bentuk permasalahan yang diajukan. Untuk penyusunan dilakukan dengan cara deskriptif yaitu dengan cara menyusun bahan-bahan hukum mengenai hukuman mati terhadap narapidana terorisme dalam perlindungan hak asasi manusia yang telah dipilih secara sistematis sehingga membentuk suatu karya ilmiah.

\section{PEMBAHASAN}

\section{Pengaturan hukuman mati terhadap terorisme dalam kaitannya dengan perlindungan hak asasi manusia}

Sesuai dalam Hukum positif di Negara Republik Indonesia, dalam mengantisipasi, mengatasi dan menanggulangi masalah kasus tindak pidana yang dilakukan terorisme, agar sesuai dengan pembukaan UUD Tahun 1945, Negara Republik Indonesia telah mempunyai beberapa peraturan yang sedang berlaku dalam hukum positif di Negara Republik Indonesia. Dalam hal tersebut Pemerintah di Negara Republik Indonesia berkewajiban untuk selalu mempertahankan suatu kedaulatan Negara dan menjunjung tinggi segala keutuhan nusa dan bangsa dari segala macam bentuk ancaman dari pelaku tindak pidana terorisme dari luar Negeri maupun dalam Negeri. Di Indonesia peraturan hukum dan perundang-undangan yang berlaku untuk tindak pidana yang dilakukan terorisme dalam hukum positif saat ini yaitu UU No. 5 Tahun 2018, KUHP, Perpres No. 77 Tahun 2019 dan Perpres No. 46 Tahun 2010.

Hukuman mati yang dijaruhkan terhadap kasus terorisme di Negara Republik Indonesia selalu menjadi pembicaraan dan perdebatan dalam berbagai kalangan di Indonesia. Penyelesaian kasus rindak pidana terhadap terorisme dengan cara hukuman mati atau atau disebut Capital Punishment dan saat ini Pemerintah Republik Indonesia telah menjalankan proses hukuman mati ini terhadap beberapa pelaku tindak pidana bagi terorisme tersebut. Mengenai amandemen Undang-undang 
Nomor 5 Tahun 2018, perubahan dari UU Nomor 15 Tahun 2003, hukuman pidana mati diatur ke dalam pasal 14 yang berbunyi: (Indroharto, et al, 1995) "setiap orang yang sudah merencanakan atau menggerakan orang lain untuk melakukan suaru tindak pidana terorisme sebagaimana yang dimaksud dalam pasal 6, pasal 7, pasal 8, pasal 9, pasal 10, pasal 11 dan pasal 12 dipidana dengan pidana mati atau pidana penjara seumur hidup."

Setelah Negara Indonesia merdeka, pemerintah melanjutkan untuk tetap menjalankan pemberlakuan hukuman mati yang ada dalam Wetboek van Strafrecht Inlanders (WvSI) yang kemudian ditetapkan menjadi KUHP. Menurut Hukum pidananya, berbagai macam aturan mengenai jenis-jenis hukuman terdapat dalam dalam bab II Pasal 10 KUHP huruf A yang menyatakan hukuman mati terdapat di dalam salah satu pidana pokok. Hukuman mati dalam hak asasi manusia Negara Lndonesiajuga sangat mengadvokasi Hak Asasi Manusia (HAM) yang menjamin bahwa hak semua warga negara sama dengan statusnya di lingkungan hukum dan pemerintahan. Indonesia merupakan salah satu negara di dunia dimana hukuman mati masih digunakan atau dijatuhi hukuman. UU No. 26 tahun 2000 tentang Pengadilan Hak Asasi Manusia mengatur hukuman mati bagi hak asasi manusia. Diantaranya, ketentuan tentang pidana mati di Pengadilan HAM tertuang dalam Pasal 36 dan Pasal 37.

\section{Upaya Hukum Narapidana Terorisme Untuk Mendapatkan Keringanan Hukum}

Perlindungan terhadap hak asasi manusia merupakan bagian utama yang sangat penting untuk penegakkan hukum termasuk dalam kepastian pelaksanaan hukuman mati terhadap narapidana terorisme yang dihukum mati. Kepastian penegakkan hukum sebagaimana telah menjadi salah satu paramerer untuk dilaksanakannya perlindungan, tidak hanya bagi korban dan masyarakat tetapi juga bagi pelaku. Upaya hukum yang ditempuh dalam memastikan dilaksanakannya eksekusi mati memiliki filosofi yang dalam, termasuk di dalamnya terhadap pencapaian keadilan dan Hak untuk mendapatkan keadilan telah menjadi bagian penting dari perlindungan HAM. Demi memperkuat serta berani menjamin perlindungan terutama mengenai hak asa I manusia (HAM) di wilayah Negara Republik Indonesia, maka dibentuklah suatu 426ntrins yang bertanggungjawab (Komnas HAM) berdasarkan ketetapan Tap MPR No. 17 tahun 1998 yang disetujui pada tanggal 23 September tahun 1999. Pentingnya peranan yang menjaminan perlindungan hak asasi manusia membuktikan bahwa komitmen terhadap kehidupan demokratis selaJu berada pada perlindungan Negara hukum.

Tindak pidana terorisme sangat jelas terjadi adanya pelanggaran terhadap hak asasi manusia khususnya para korban dari pelaku terorisme tersebut terutama dalam hak untuk hidup dan bebas dari rasa takut serta ancaman. Pelaku tindak pidana terorisme meskipun melakukan tindakan yang tidak manusiawi tetap memiliki hak asasi manusia. Sehingga meskipun terorisme ditetapkan sebagai kejahatan extra ordinary crime yang memerlukan penanganan yang khusus (extra enforcement) tidak dapat dijadikan sebagai alat atau tameng untuk pelanggaran HAM terhadap pelaku meski akan muncul dilematis tersendiri di dalam prosesnya. (Wahid, 2004) Narapidana terorisme mempunyai hak memperoleh keadilan yang dimana setiap orang mempunyai status ataupun sederajat dihadapan hukum. Prinsip ini tertuang ke dalam pasal 7 (UDHR), pas al 26 (ICCPR), pasal 27 (I), pasal 28 huruf D UUD I 945. Mengenai beberapa hak yang berada di dalam yurisdiksi pada dasarnya merupakan sebuah prinsip dalam hukum pidana dan acara pidana, akan tetapi tidak semuanya bisa terbatas oleh hukum pidana dan hukum acara. Setiap orang sangat berhak untuk meminta maupun menerima peradilan yudisial dengan mengajukan beberapa permohonan, pengaduan, dan litigasi dalam kasus pidana, kasus perdata, dll.

Hukum selalu menyatakan, apabila ada hak yang dilanggar, maka selalu ada kemungkinan untuk menuntut dan memperoleh keadilan. Dalam arti lain terorisme yang sudah dijatuhi pidana mati atau dalam masa tunggu pelaksanaan eksekusi maka narapidana tersebut masih mempunyai hak memperoleh perlindungan hak asasi manusia. Terpidana yang sudah divonis oleh putusan pengadilan selalu berupaya untuk mencari keadilan dalam perlindungan hak asasi manusia, upaya-upaya yang dilakukan terpidana mati terhadap terorisme secara umum hak 
terpidana terdiri atas hak hukum dan hak kemanusiaan baik yang dilaksanakan sebelum maupun menjelang eksekusi mati.

Upaya hukum terhadap narapidana terorisme yang dihukum mati merupakan hak mutlak yang harus diberikan oleh hukum kepada para pihak didalam suatu kasus yang berperkara. Upaya hukum yang dilakukan tersebut tetap melandaskan pada hak asasi manusia yang dimana sesungguhnya merupakan bagian dari kemanusiaan yang paling 427ntrinsic. (Muhtaj, 2008). Menurut pasal 1 angka 12 UU No. 8 tahun 1981 mengenai KUHAP, upaya atau bantuan hukum merupakan hak terhadap pelaku kejahatan atau jaksa berhak untuk melakukan upaya hukum atau bantuan dan tidak menerima pembelaan yang bertentangan, seperti meminta pencabutan hukuman asli terhadap hak terpidana. Permintaan pertimbangan ulang dibuat dengan cara yang ditentukan oleh undang• undang untuk mengurangi undang-undang tersebut. Bentuk upaya ataupun bantuan hukum terbagi menjadi beberapa bagian utama yaitu seperti upaya bantuan hukum biasa dan upaya bantuan hukum luar biasa. Langkah-langkah bantuan hukum yang umum termasuk naik Banding ke Pengadilan dan pengajuan naik banding ke MA, sementara upaya bantuan hukum khusus mencakup pemeriksaan tingkat kasasi demi sebuah kepentingan hukum hingga meminta peninjauan kembali, serta tindakan non-hukum lain yang dapat diajukan terdakwa, terpidana atau narapidana yang termuat di luar hukum acara pidana antara lain seperti mengajukan Grasi, Amnesti dan Abolisi. Dasar hukum yang digunakan yaitu pasal 14 Undang-undang Negara Republik Indonesia Tahun 1945. (Pangaribuan, 2008).

\section{KESIMPULAN DAN SARAN}

\section{Kesimpulan}

Berdasarkan penjelasan diatas, peneliti dapat menarik kesimpulan sebagai berikut:

1. Pengaturan hukuman mati terhadap terorisme yang terkait dengan perlindungan hak asasi manusia, terdapat beberapa ketentuan yang mengatur Hukuman Mati bagi terorisme. Pengaturan terorisme dalam hukum positif diatur dalam Undang-undang No. 5 Tahun 2018, KUHP, Perpres No. 77 Tahun 2019 dan Perpres o. 46 Tahun 2010. Hukuman Mati terhadap tindak pidana terorisme diatur dalam pasal 14 UU No. Tahun 2018. Dalam KUH P pasal 10 huruf A sebagai pidana pokok dan Undang-undang Nomor 26 Tahun 2000.

2. Upaya hukum narapidana terorisme untuk mendapatkan keringanan hukum merupakan sebuah kebijakan hukum yang memiliki sebuah ide dasar dalam perlindungan hak asasi manusia. Upaya hukum terhadap narapidana terorisme yang dihukum mati merupakan hak yang wajib diberikan kepada para pihak didalam suatu perkara. Narapidana terorisme yang sudah divonis hukuman mati masih mempunyai kesempatan dalam mengurangi hukuman tersebut yang sudah diputus oleh pengadilan dengan melakukan upaya-upaya hukum tersebut mulai dari upaya mengajukan banding, kasasi, peninjauan kembali hingga pengajuan terakhir untuk meminta pengampunan dari Presiden yang menjadi harapan satu-sarunya terpidana untuk mengurangi hukuman tersebut demi mendapatkan perlindungan hak asasi manusia dan keringanan hukum.

2. Saran

Melalui penelitian ini, peneliti ingin menyampaikan beberpa saran yang diharapkan dapat membantu pemerintah dalam menetapkan dan mempertimbangkan hukuman mati bagi para terdakwa, yaitu:

1. Kepada Pemerintah Negara Republik Indonesia diharapkan untuk lebih mempertimbangkan sebagaimana mestinya mempertegas dalam menetapkan pelaksanaan pidana mati untuk tetap dijadikan sebagai hukum pidana pokok seperti yang tercantum dalam pasal 10 huruf A, KUHP maupun menghapus hukuman mati sebagai pidana pokok. Karena hukuman mati tersebut membuat munculnya perdebatan antara yang setuju dengan pemberlakuan pidana mati maupun yang tidak setuju karena berlandaskan pada pembukaan UUD 1945 dan Undang-undang omor 39 Tahun 1999 tentang Hak Asasi Manusia. Pemerintah harus berani mencari jalan keluar agar hukum 
maupun segala bentuk peraturan yang berlaku di wilayah Negara Indonesia tidak sal ing bertentangan unruk memicu munculnya berbagai konflik, seperti konflik terhadap hukuman mati ini dengan hak asasi manusia.

2. Kepada masyarakat diharapkan tetap berlandaskan pada UUD 1945 dan mentaatin segala bentuk aturan-aturan hukum yang berlaku di Negara Republik Indonesia. Seperti halnya tidak melakukan suaru tindak pidana terutama melakukan tindak pidana berat yang bisa yang bisa membahayakan bagi masyarakat, korban maupun pelaku. Karena ji ka masyarakat sud ah melakukan tindak pidana terutama tindak pidana berat maka hukum yang diterima oleh pelaku mendapatkan sanksi pidana mati.

3. Kepada pelaku diharapkan bisa menjadi contoh terhadap masyarakat bilamana masyarakat yang ingin melakukan suatu tindak pidana maka setiap perbuatan memiliki sanksinya masing-masing dan harus berani mengambil resiko terhadap setiap perbuatan kejahatan.

\section{DAFTAR BACAAN}

Anjari, W. (2018). Penjatuhan Pidana Mati Di Indonesia Dalam Perspektif Hak Asasi Manusia. E-Journal Widya Yustisia, Vol.1(2).

Arief, A. (2019). Problematika Penjatuhan Hukuman Pidana Mati Dalam Perspektif Hak Asasi Manusia Dan Hukum Pidana. Komsik Hukum, Vol.19(1).

Firmansyah, H. (2011). Upaya Penanggulangan Tindak Pidana Terorisme di Indonesia. Jurnal Mimbar Hukum, Vol. 23(2).

Indroharto, et al. (1995). Kapita selekta hukum, mengenang almarhum Prof H. Oemar Seno Adji SH. Ghalia Indonesia, Jakarta.

Muhtaj, M. EL. (2008). Dimensi-dimensi HAM: mengurai hak ekonomi, sosial, dan budaya. Raja Grafindo Persada, Jakarta.

Pangaribuan, L. M. P. (2008). Hukum Acara Pidana: Surat-surat Resmi di Pengadilan oleh Advokat. Djambatan, Jakarta.

Prakoso, D. (1987). Masalah pidana mati. Bina Aksara, Jakarta.

Smith, R. K. M. (2008). Hukum Hak Asasi Manusia. PUSHAM Uii, Yogyakarta.

Sumanto, atet. (2004). Kontradiksi Hukuman Mati di Indonesia Dipandang dari Aspek Hak Asasi Manusia. Agama dan Para Ahli Hukum. Jurnal Perspektif, Vol.9(3).

Wahid, A. (2004). Kejahatan terorisme: perspektif agama, HAM dan Hukum (Cet.1). Refika Aditama, Bandung 